\title{
The Execution of Rughobursing: the political economy of convict transportation and penal labour in early colonial Mauritius ${ }^{1}$
}

\section{Clare Anderson \\ School of Historical Studies \\ University of Leicester}

On Wednesday 29 October 1834 at 2.00 pm, a convict named Rughobursing was taken to the outskirts of Port Louis, the capital of the British Indian Ocean colony Mauritius. His destination was Plaine Verte, the usual place of public execution, for four days earlier the Court of Assizes had sentenced him to death. Rughobursing spoke his final words through Faride Dina, the government interpreter. They were recorded, and the statement was signed by the officials present - G. Leffray, the Judge of the Court; H. Bury, the Clerk; and Faride Dina. It read: "“Ghunna had hit him first and so he had to hit him back. He did not know if Ghunna was dead or not. It was also him [Ghunna] who had attacked John Hewett and Patrick Hagan"”. Finally, that "“it was him [Ghunna] who had committed the crime for which he is condemned."' Thus declaring his innocence,

\footnotetext{
${ }^{1}$ This paper was first presented at the Cultures of Confinement Workshop, School of Oriental and African Studies, June 2001. I thank participants for their comments. I would also like to thank archivists in the Mauritius Archives (MA), India Office Library (IOL), Public Records Office (PRO) and Tamil Nadu State Archives (TNSA) for their help. The British Academy, British Academy Southeast Asia Committee, Carnegie Trust for the Universities of Scotland and Economic and Social Research Council have generously supported my work on convict transportation. 
Rughobursing, thirty-five years old, was handed over to the executioner and put to death by guillotine. ${ }^{2}$ His right of appeal had been denied. ${ }^{3}$

Rughobursing's execution took place six years after he had been transported from the Bengal Presidency to Mauritius, the destination for some 1500 Indian convicts between 1815 and $1837 .{ }^{4}$ During this period, the East India Company also shipped convicts to Penang, Singapore and Malacca. ${ }^{5}$ After 1828, new British settlements in Arakan and the Tenasserim Provinces (Burma) received Indian convicts too. Earlier shipments to Bencoolen had ended in 1825, when the settlement was returned to Dutch control. Most convicts in the penal settlements were put to labour on public works projects. Some built and repaired roads and bridges, cleared land and quarried stone. Others worked in agriculture, cultivating commercial products like silk, spices and tea. A significant minority were employed as overseers, clerks and cooks within the convict departments or hired out to private settlers.

The first Governor of Mauritius, R.T. Farquhar, took up the position after serving as Lieutenant-Governor of Penang, which had been a penal settlement since 1789. He was thus well versed in the utility of convict labour, and shortly after he arrived in Mauritius he wrote to the Indian authorities requesting a supply. At the time, either government slaves or corvée slaves were employed on public works; slave owners being obliged to lend each of their slaves to government for four days per year. This labour

\footnotetext{
${ }^{2}$ MA JA52: Report of G. Leffray, H. Bury and F. Dina, 29 Oct. 1834 (translation from French my own).

${ }^{3}$ MA Z2A78: E.A. Williams, Substitute Procureur Général, to J. Finniss, Chief of Police, 29 Oct. 1834.

${ }^{4}$ For a more detailed account of the political economy of convict transportation to early colonial Mauritius, see my own Convicts in the Indian Ocean: transportation from South Asia to Mauritius, 1815-53, London, 2000.

${ }^{5}$ C.M. Turnbull, 'Convicts in the Straits Settlements, 1826-67', Journal of the Malay Branch of the Royal Asiatic Society, 43, 1, (1970), pp. 87-103.
} 
supply was hopelessly inadequate for building and maintaining the island's infrastructure, especially after the abolition of the slave trade in 1807. Farquhar saw convicts as a solution to this shortage, a cheap and more controllable alternative to the hiring of local contract labourers. Indentured labour migration had not yet got underway. In comparison to the population of slaves in Mauritius, and the half million indentured labourers who migrated to the island after 1834 , the number of convicts transported to the island was relatively small. Indeed the first Census of 1826 recorded a population of 9,000 whites, 14,000 Indians, Chinese and creoles (Mauritian-born) and 63,000 slaves. ${ }^{6}$ At the time, there were just over five hundred convicts on the island. ${ }^{7}$ However, despite their limited numbers, convicts were highly valued and much praised for building the communications necessary for the further development of the sugar industry. Indeed, the archives are replete with petitions from plantation owners all over the island calling for an increase in the number of convicts employed in the districts. ${ }^{8}$ I would argue that transportation transformed convicts into 'penal labourers'. ${ }^{9}$ They were punished through work, becoming economically productive labourers and actors in what we might term the colonial theatre of punishment. ${ }^{10}$ The lessons of punishment were both directed at convict gangs and projected back to India, where from the beginning of the nineteenth century

\footnotetext{
${ }^{6}$ PRO CO172/42: Baron d'Unienville, Tableaux de Statistiques, no. 6.

${ }^{7}$ IOL P/139/32: Numerical Return of Bengal Convicts shewing the Casualties that have occurred from the year 1815 to 31 st July 1829 inclusive.

${ }^{8}$ Anderson, Convicts in the Indian Ocean, p. 44.

${ }^{9}$ A phrase borrowed from Raymond Evans and William Thorpe's assessment of convict labour in colonial Moreton Bay (Queensland), 'Power, Punishment and Penal Labour; Convict Workers and Moreton Bay', Australian Historical Studies, 25, 98 (1992), p. 109.

${ }^{10}$ On punishment, profit and signification, see Michel Foucault, Discipline and Punish: The Birth of the Prison, London, 1977, p. 109.
} 
prisoners had a relatively sophisticated understanding of what transportation entailed. ${ }^{11}$

This article seeks to explore the events leading to Rughobursing's execution as a means of untangling some of the complexities of this economic, social and penal transformation.

On March 18 1826, Rughobursing was sentenced to imprisonment for life in Calcutta's Alipur Jail, the largest penal institution in India. He had been convicted of 'wounding two persons so as to cause their death and wounding two other persons', though we know nothing more about the case. We are on firmer ground with his social origins. Rughobursing was from Benares, and a Bhumihar: a Brahmin community which had taken up agriculture. ${ }^{12}$ He was literate enough to sign his name on his later court statements. Like many convicts transported from inland areas of the Bengal Presidency (and later indentured labourers) he probably spoke Bhojpuri. Two years after Rughobursing was sent to jail he applied for the commutation of his sentence to transportation. All life prisoners were entitled to apply for such a commutation, a privilege that was granted in 1828 due to the weight of their demands. ${ }^{13}$ Shortly after submitting his petition, Rughobursing was shipped to Mauritius on the Lord Amherst, together with thirty-nine other convicts. The ship left Calcutta on June 19 1828, arriving in Mauritius almost two months later on August $16 .^{14}$

\footnotetext{
${ }^{11}$ Clare Anderson, 'The Politics of Convict Space: Indian penal settlements and the Andamans', in Alison Bashford and Carolyn Strange, eds, Isolation: places and practices of exclusion, London, 2003, pp. 40-55.

${ }^{12}$ K.S. Singh, People of India, Volume IV: India's Communities, $A$ - $G$, New Delhi, 1998, pp. 470-3.

${ }^{13}$ Parliamentary Papers 1830 XXVIII: A Regulation for empowering the Governor-General to commute Sentences of Imprisonment for Life in the Allypore Gaol, to Transportation for Life to any of the British Settlements in Asia, in certain cases, 10 Apr. 1828. For more details of prisoner petitioning, see my 'The Politics of Convict Space', pp. 40-55.

${ }^{14}$ IOL P/138/65: J. Master, Superintendent of Alipur Jail, to H. Shakespear, Secretary to Government Bengal, 31 May 1828.
} 
At the time of Rughobursing's conviction in India, legislation was in place directing that all life convicts convicted in the Bengal Presidency should have their name, crime and date of sentence tattooed on the forehead, in the vernacular. ${ }^{15}$ These tattoos were known as godna (godena); and were made with indelible blue dye, mixed from burnt indigo and soot. Godna was designed as an irrevocable mark of both individual and collective criminal identity. Different types of tattoos could even delineate convicts as part of a criminal sub-population, notably thugs, of whom hundreds were transported overseas, mainly to the Tenasserim Provinces, from the 1830s. Rughobursing was also tattooed, though we do not know the details of the inscription, as we do for some other convicts. His descriptive roll, compiled for the purpose of identification, read: 'Brown colour, wide forehead, joint eyebrows, sheep's eyes, nose high, both ears bored, moderately stout, height 5 feet $81 / 3$ inches, aged 25 years, marked on the forehead by the process called Godena'. ${ }^{16}$

Godna was supposed to act as a deterrent against escape, a particular risk when prisoners were put to work on extra-mural labour, as they were in India until shortly after the publication of the Report of the Committee on Prison Discipline in $1838,{ }^{17}$ or sent to penal settlements overseas like Mauritius. Its purpose was twofold. First, marked convicts

\footnotetext{
${ }^{15}$ IOL V/8/17: Regulations passed by the Governor-General in Council, volume II, 1796-1803, Calcutta, 1803, p. 387. For a more detailed discussion of godna, see my 'Godna: inscribing Indian convicts in the nineteenth century', in Jane Caplan, ed., Writing on the Body: the tattoo in European and North American History, London, 2000, pp. 102-17, and my forthcoming Legible Bodies: race, criminality and colonialism in South Asia, Oxford, 2004, ch. 2.

${ }^{16}$ MA JB266: Extract from List of Convicts embarked per Lord Amherst, 19 June 1828 (convict no. 11 Rughobursing).

${ }^{17}$ IOR P/141/9: Second and Concluding Report of the Committee of Convict Labour, 28 Jan. 1837; Report of the Committee on Prison Discipline, 8 Jan. 1838, Calcutta, 1838, p. 17.
} 
were unable to pass themselves off as free. Second, ideally tattoos pointed to particular written records. This facilitated the recognition of groups of convicts and individuals, making the recapture of escaped convicts by colonial officials, or local communities in India and the penal settlements easier. The Governor of the Straits Settlements (Singapore, Penang and Malacca) wrote in 1842 that a mark on the forehead was often the only means to distinguish convicts from free Indians or other settlers. ${ }^{18}$ When transportation from Bombay to Mauritius began in the late 1820s, there was an explosion in convict desertion (marronage), for Bombay convicts were not tattooed on the forehead. Added to the increasing number of indentured Indian labourers migrating to the island, Bombay convicts were able to escape into the Indian population without difficulty. ${ }^{19}$

After Rughobursing's transportation ship, the Lord Amherst, arrived in Mauritius, the convicts on board were sent to Grand River just outside Port Louis, where the convict headquarters were located. ${ }^{20}$ Typically, after arrival Indian convicts were separated into working parties of between thirty and forty men, and employed on public works all over the island, often at some distance from Grand River. The convict system was driven by the economic wants of new British territories like Mauritius - the desire for cheap labour to build infrastructure. The despatch of transportation ships across the Indian Ocean and to Southeast Asia depended entirely on each settlement's willingness to receive convicts. If they would not take them, convicts were not sent. However, in order to guarantee a

\footnotetext{
${ }^{18}$ IOL P/403/15: S.G. Bonham, Governor Straits Settlements, to J.P. Willoughby, Secretary to Government Bombay, 12 Nov. 1842.

${ }^{19}$ MA Z2A62: W. Staveley, Head of Convict Department, to Finniss, 13 Apr. 1831.

${ }^{20}$ MA RA383: Staveley to G.A. Barry, Secretary to Government Mauritius, 18 Sept. 1828.
} 
continuing supply of convicts, the settlements had to assure the Indian presidencies that their penal concerns were being satisfied. It was not unknown for the presidencies to cut off the convict flow if they felt offenders were not being properly punished. In the mid1830s, for instance, the Madras Government suspended transportation to the Straits Settlements, because it believed that the sentences of hard labour passed on all transportation convicts from the presidency were not being carried out there. It only resumed transportation after Madras Presidency convicts in the Straits were transferred to the Tenasserim Provinces, to where new shipments were subsequently sent. ${ }^{21}$

Penal settlements worked hard to convince the mainland authorities that the labour performed by convicts was both a punishment and a means of reform. As early as 1797, the East India Company had written of hard labour in the penal settlements as a means through which convicts could be restrained from 'habits of idleness and dissipation. ${ }^{22}$ By the time regulations were passed for the organisation of convicts in Mauritius in 1818, the amount of labour necessary to effect moral reformation had been calculated precisely, conveniently dovetailing with the nine to ten hour working day. ${ }^{23}$ Two years later, T.S. Raffles spoke of the aim of transportation to Bencoolen: reclaiming

\footnotetext{
${ }^{21}$ TNSA Madras Judicial Proceedings (henceforth MJP) vol. 291: J.F. Thomas, Register Faujdari Adalat (criminal court), to F.R. Wheatley, Chief Secretary to Government Madras, 22 Aug. 1835; TNSA MJP vol. 306A: W. Douglas, Register Faujdari Adalat, to H. Chamier, Chief Secretary to Government Madras, 25 Apr. 1836; TSNA MJP vol. 310: Chamier to W.H. Macnaughten, Secretary to Government of India, 12 July 1836.

${ }^{22}$ IOL P/128/34: John Shore Baronet, to Jon Duncan, Governor of Bombay, 1 Sept. 1797.

${ }^{23}$ PRO CO167/41: Governor R.T. Farquhar to Lord Bathurst, Secretary of State for the Colonies, 18 July 1818, enclosing Minute on the Employment of the Convicts at Mauritius. See also Anderson, Convicts in the Indian Ocean, ch. 3.
} 
convicts from their 'bad habits. ${ }^{, 24}$ The Superintendent of Convicts in Penang wrote in 1824 that 'a most material and favourable change is undeniably in progress in the morals and habits of this hitherto depraved and useless class of people'. ${ }^{25}$ Across the settlements, this moral transformation was spoken of through a language of labour, discipline, surveillance, vigilance and control. There was also the claim that convicts were not only separated from their former kin networks, but prevented from interacting with local populations. During the early years of transportation to Mauritius, for instance, convicts were forbidden from interacting with slaves (all contact was banned in 1818). ${ }^{26}$

Given the conflicting aims of the presidencies and the penal settlements, it is perhaps inevitable that there were massive contradictions between discourses of penal labour and practices of convict management. Many of these were drawn out in the Report of the Committee on Prison Discipline (1838), which although mentioning Mauritius only in passing (it was not Company territory) complained of the generally lax treatment that convicts elsewhere enjoyed, particularly in the Straits Settlements. It called for 'the strict and uniform observance of the rules' and for the labour of convicts to be 'turned to the best account. ${ }^{27}$ The administrators of the penal settlements were faced with two main difficulties in this respect. First, a continuing supply of convicts could only be procured if they could convince the authorities in India that they had a penal agenda. However, from the first years of transportation, it was clear to the settlements that if the system was to operate successfully, practices of convict management had to be flexible. If the prospect

\footnotetext{
${ }^{24}$ IOL P/134/48: Governor T.S. Raffles to W.B. Bayley, Secretary to Government Bengal, 27 June 1820.

${ }^{25}$ IOL P/136/23: J.W. Hull, Superintendent of Convicts Penang, to E. Presgrave, Acting Secretary to Government Fort Marlborough, 1 Jan. 1824.

${ }^{26}$ PRO CO167/37: Acting Governor Hall to Bathurst, 28 Jan. 1818.

${ }^{27}$ Report of the Committee on Prison Discipline, p. 12 (recommendation 51).
} 
of limited freedoms was not held out to convicts - most of whom were transported for life - they would have little incentive to work efficiently and be more likely to abscond. Thus convicts were permitted freedoms that frequently surprised the Indian authorities.

Second, the employment of convicts on infrastructural projects invariably required their wide dispersal over large areas. This spatial dynamic meant that it was not unusual for working parties to be based some hours, if not days, away from convict headquarters. This made uniform discipline, particularly in relation to social segregation, a practical impossibility.

Convicts in all the penal settlements struck up multiple relationships with local populations. Mauritian convicts traded with slaves, creoles and, after the abolition of slavery, apprentices (ex-slaves) and indentured labourers. They gambled, smoked and drank with them, married them and had children. As I have argued elsewhere, this autonomy was ignored, tolerated or even encouraged by the local authorities in Mauritius, for it encouraged economic self-dependency and social stability. ${ }^{28}$ Yet this clashed with the mainland penal agenda, as an 1805 report into convict discipline in Bencoolen reveals. R.S. Perreau, Magistrate and Superintendent of Convicts in Bencoolen, responded to criticisms from India in this respect: 'I had no place of close confinement for [convicts]; nor could I confine them employed in labour miles from each other. I could not check their sexual behaviour with women, which I am blamed for. Neither am I a reformer of their morals. My duty was to provision them; work them; and to prevent disturbances. $^{29}$

\footnotetext{
${ }^{28}$ Anderson, Convicts in the Indian Ocean, ch. 5.

${ }^{29}$ IOL P/129/22: R.S. Perreau, Magistrate and Superintendent of Convicts Bencoolen, to T. Parr, Resident Bencoolen, 4 Oct. 1805.
} 
By 1829, Rughobursing had been moved to Rivière du Rempart, a northern district of Mauritius. It was here that he had his first run in with the authorities, attempting to strike his overseer, Donald Cormack, with a crow bar. ${ }^{30}$ European overseers were an obvious target for assault. Although there are no records of what precipitated Rughobursing's attack, one can trace the sort of grievances that provoked others. At about the same time, in Malacca, Overseer Wiggins was murdered by a convict who had been flogged and sent to the chain gang for neglect of duty. ${ }^{31}$ Some years later, a group of convicts in Kyaukpyu (Arakan) who had been refused admission into hospital when they said they were ill attacked their jailor, Mr Colombs. ${ }^{32}$ In punishment for his attempted assault, Rughobursing was put in heavy irons for two months and sent back to Port Louis, close to the Grand River convict headquarters, later that year. ${ }^{33}$

At the end of 1829, Rughobursing was arrested and charged with the attempted murder of two of his convict camarades, Looteeah and Kalooa. ${ }^{34}$ It was alleged that he had beaten Looteah so badly that his skull was fractured and he almost died. ${ }^{35}$ The day after the attack, with Looteah lying seriously injured, the police interviewed Kalooa and Rughobursing. Kalooa said that he had gone to buy some potatoes with Looteah from a Sunday market. Shortly afterwards, a third convict came up to them and demanded they

\footnotetext{
${ }^{30}$ MA JB221: Extract Convict Punishment Book, Rivière du Rempart, 8 Aug. 1829.

${ }^{31}$ IOL P/140/49: S Garling, Resident Councillor Malacca, to S.G. Bonham, Acting Governor Straits Settlements, 10 Apr. 1834.

${ }^{32}$ IOL P/144/54: H. Hopkinson, Commissioner Arakan, to H. Pratt, Under Secretary to Government Bengal, 12 Jan. 1854.

${ }^{33}$ MA JB221: Police Report, 7 Dec. 1829, and Extract Convict Punishment Book, Rivière du Rempart, 8 Aug. 1829.

${ }^{34}$ MA JB211: Verdict of the Court of First Instance, 13 Mar. 1830.

${ }^{35}$ MA JB221: Report of Alex Montgomery, Surgeon Civil Hospital, 7 Dec. 1829.
} 
give him the potatoes. He had not known the man's name, but now recognised him as Rughobursing. Loteeah refused, and so the man beat him up. When Kalooa intervened, he was also assaulted. As far as he was aware, no convicts held a grudge against Loteeah, and Rughobursing had not been provoked. When Rughobursing was questioned, he denied all knowledge of the incident. He claimed that he had seen Kalooa and Looteah that day on his way to market, and that they were so drunk that they had fallen over. They saw him, so he suspected that they might accuse him of something untoward. ${ }^{36}$

When the case came to trial, Kalooa and Looteah repeated their story, and Rughobursing again claimed that he knew nothing about their injuries. Unfortunately for him, Jean Marie Giotot and his slave Mercure, the potato sellers, had witnessed the assault and positively identified Rughobursing as the assailant. ${ }^{37} \mathrm{He}$ was found guilty, but because he was already under sentence of transportation the court was not empowered to punish him further. They sent him back to the discipline of his working party, their only penal option. ${ }^{38}$ The Procureur Général, concerned that Rughobursing was escaping the full penalty of the law, referred the case to the Court of Appeal. It sentenced him to two years' imprisonment, and he was transferred to Port Louis jail. ${ }^{39}$

Indian penal settlements promoted a system of convict management that employed both incentives and punishments. Incentives included assignment to preferred tasks, removal from road gangs, or gratuities in cash or kind. In Mauritius, for instance,

\footnotetext{
${ }^{36}$ MA JB211: Police Report, 7 Dec. 1829.

${ }^{37}$ MA JB221: Court of First Instance, cross-examination of Jean Marie Giotot, Mercure and Rughobursing, 21 Dec. 1829, 19 Feb. 1830, 13 Mar. 1830.

${ }^{38}$ MA RA433: Police Report, 13-15 May 1830.

${ }^{39}$ MA RA437: Prosper d'Epinay, Procureur Général, to Barry, 28 June 1830; MA JA41: Sentence of the Court of Appeal, 9 July 1830.
} 
each convict was paid one rupee per month as an encouragement to 'efficient labour'. ${ }^{40}$ Governor Farquhar wrote: 'those who are laborious, decent, orderly, and respectful, may benefit proportionately'. ${ }^{41}$ Similar rules were passed in early Bencoolen. ${ }^{42}$ In 1820 the Bencoolen Regulation for the Better Management of the Bengal Convicts divided convicts into three classes, according to the length of time they had spent in the settlement and their subsequent behaviour. Deserving convicts were employed as artificers or in the salt works and received a monthly gratuity. Other privileges related to their lodgings, freedom of movement and access to the courts. ${ }^{43}$ Five years later, the Bencoolen Regulation was adapted for Penang, Singapore and Malacca. ${ }^{44}$ It then provided the basis for the Straits' more complex Butterworth Rules, adopted across the Settlements in $1845 .{ }^{45}$ The ultimate incentive for a convict was a ticket-of-leave. After a certain period of time, convicts were released from labour and allowed to live at large, on the condition that they steered clear of the police and the courts. In one of the most radical experiments in penal rehabilitation of the nineteenth century, from 1806 ticket-of-

${ }^{40}$ PRO CO415/15: Barry to Rossi, 27 Jan. 1816; Recueil Complet des Lois et Réglemens de l'ile Maurice, ou ile de france; Tome Premièr, Cinquième Partie, Port Louis, 1823: Proclamation 193, 24 Jan. 1816.

${ }^{41}$ PRO CO167/41: Farquhar to Bathurst, 18 July 1818, enclosing Minute on the Employment of the Convicts at Mauritius.

${ }^{42}$ IOL P/129/32: Rules for the Management of Convicts in Bencoolen, 18 June 1800; A regulation for the management of the convicts transported from Bengal to Fort Marlborough, 5 Aug. 1806.

${ }^{43}$ IOL P/134/48: Bencoolen Regulation for the Better Management of the Bengal Convicts, 5 Oct. 1820.

${ }^{44}$ IOL P/136/66: Minute on the Management of Convicts at Prince of Wales' Island [Penang], 8 Mar. 1825; IOL P/137/37: J. Crawford, Resident Singapore, to Bayley, 20 Apr. 1825; IOL P/142/37: Regulations for Convict Management, Singapore, 23 June 1825 (revised 1 Dec. 1825).

${ }^{45}$ IOL P/142/37: Governor W.J. Butterworth to A. Turnbull, Under Secretary to Government Bengal, 26 Feb. 1845 . 
leave convicts in Bencoolen were given land, seeds and livestock; and were allowed to pass the fruits of their labour - and their land allocation - on to their heirs. ${ }^{46}$

There was also a catalogue of punishments for convicts who breached regulations. They could be moved down the hierarchy of punishment, losing privileges; made to wear heavy irons, flogged, placed in the stocks, or put to harder labour. If they broke the law, they could be tried in court, and imprisoned or retransported (in the case of Mauritius, to Robben Island or one of the Australian settlements). One Bengal official eloquently summed up the aim of the 1820 Bencoolen class system thus: 'the influence resulting from the desire of promotion on one hand and the fear of degradation on the other must have the most beneficial operation on the conduct of the prisoners. ${ }^{47}$ Colonial officials claimed that the system reformed convict souls, but only through the threat or performance of particular interventions on their bodies. In this sense, there was more of a mutual interdependence than a decisive shift in penal strategies, which were themselves interlinked with the development of early colonial economies. I am reminded here of Foucault's description of the material basis of power relations: the mutual exclusivity of 'the accumulation of men and the accumulation of capital'. ${ }^{48}$

Rughobursing was released from jail a month after his imprisonment because the jail authorities had been unable to control him. They reported that in one incident he had almost killed another inmate. The Chief of Police, John Finniss, reported that Rughobursing strode about the prison, claiming that he was afraid of nothing, not even

\footnotetext{
${ }^{46}$ IOL P/129/32: A regulation for the management of the convicts transported from Bengal to Fort Marlborough, 5 Aug. 1806.

${ }^{47}$ IOL P/135/19: H.J. Prinsep, Acting Secretary to Government Bengal, to Raffles, 6 June 1822.

${ }^{48}$ Foucault, Discipline and Punish, p. 221.
} 
death. He said that he had already killed three people, perhaps a reference in part to the crime for which he had been transported. Other prisoners were apparently afraid of Rughobursing and what might happen next. The Chief Medical Officer examined him, and concluded that he was suffering from a temporary mental derangement. He was sent to hospital while Finniss petitioned that he be taken off his hands. Superintendent William Staveley ordered that Rughobursing be returned to the Convict Department and once again worked in the heaviest irons there. ${ }^{49}$

A few years later Rughobursing was moved to the district of Savanne in the south of the island. It was here that the events for which he was sentenced to death took place. In July 1834, Rughobursing brutally attacked another convict named Ghunna, the convict commander of his working party. He also assaulted three officials: the Superintendent of Convicts in the district, John Hewitt, and two overseers named Joseph Workmen and George Harrison Carter. This time, Rughobursing admitted what he had done, but his claim about the motive for the attack contradicted what Ghunna and the overseers said. Before he died, Ghunna was interviewed by the police. He said that Rughobursing had attacked him because in his capacity as convict commander, he had recently punished him for working after hours. ${ }^{50}$ If this was the case, Rughobursing's complaint that he had been reprimanded by his commander for working after hours would have been a serious one, for such entrepreneurship was normally encouraged. ${ }^{51}$ Rughobursing, however, made a more complex claim. He said that Ghunna owed him money for a piece of blue

\footnotetext{
${ }^{49}$ MA RA431: Finniss to Barry, 21 Aug. 1830, enclosing Police Report, 18 Aug. 1830; Staveley to Finniss, 9 Sept. 1830. See also MA RA435: Police Report, 19-20 Aug. 1830.

${ }^{50}$ MA JB266: Police Report, 11 July 1834.

${ }^{51}$ Anderson, Convicts in the Indian Ocean, pp. 107-8.
} 
cloth he had sold him on credit. Each time he had asked for the cash, Ghunna threatened to tell the European overseers, or to have him put in the stocks. Rughobursing added that some time previously he had given Hewitt, Workmen and Carter a not insubstantial bribe of fifteen piastres (Spanish dollars) on the promise that he would be made a convict commander. They had pocketed the money and gone back on their word. Since then, Hewitt had treated him so badly that he had complained to the Surveyor General, J.A. Lloyd (by this time, the officer in charge of convicts). ${ }^{52} \mathrm{~A}$ month after the attack, Ghunna died. He had multiple stab wounds to and fractures of the face, some of which had turned gangrenous. ${ }^{53}$ And so Rughobursing was charged with murder. In October the Court of Assizes found him guilty and he was sentenced to death. ${ }^{54}$

Precariously balanced within the system of rewards and punishments were those few convicts, like Ghunna, selected to oversee their fellow transportees. Their duties included taking the daily roll calls, marching their working party to and from work, overseeing labour, and administering punishments for petty misdemeanours. These convicts - known variously as commanders, cotwals, jemadars or tindals - were supposed to be promoted on the basis of continued good behaviour, though it is possible that those with access to financial resources were able to secure the position. Convict commanders could be removed from their position at any time, a humiliating and socially isolating experience. One Mauritian commander, Mattadon, who was removed from his post in 1819, even hanged himself rather than return to a working party. ${ }^{55}$ That there was the

\footnotetext{
${ }^{52}$ MA JB266: Court of First Instance, Evidence of Rughobursing, 11 Aug. 1834.

${ }^{53}$ MA JB266: Report of A. Montgomery, Civil Surgeon, 17 Aug. 1834.

${ }^{54}$ MA JB266: Sentence of the Court of Assizes, 25 Oct. 1834.

${ }^{55}$ MA RA142: Rossi to Barry, 29 Nov. 1819.
} 
potential for resentment against convict commanders is hardly surprising, for they enjoyed considerable privileges, in terms of financial and other advantages. By 1823, there were forty commanders in Mauritius, each entitled to a gratuity of $£ 1-4-0$ per month, in addition to their usual rations and monthly payment of one rupee. ${ }^{56}$ Tindals elsewhere in the Southeast Asian settlements enjoyed similar privileges. ${ }^{57}$ Yet attacks against convict commanders were quite unusual; in most cases, they were assaulted during the course of an escape attempt. ${ }^{58}$ Commander Ghunna, however, had been attacked before. Earlier in 1834 a convict named Malagee Naragee had stabbed him, though we do not know why. Overseer Hewitt had been attacked at the same time. ${ }^{59}$ A position of command was something that convicts could aspire to, and the authorities thought this encouraged good behaviour. The Superintendent of Convicts in Singapore, G.D. Coleman, summed up the system thus: 'It is ... good policy to make it as comfortable and well worth having as possible, for it is to the competition for chapras [badges of authority] among the most enterprising and intelligent; that having nothing to hope for would be most likely to be seditious. I attribute the general good conduct of the convicts to this. ${ }^{60}$ What Coleman did not mention were other benefits convict commanders could hope to gain, for there is evidence to suggest that some were well versed in bribery and extortion. It is possible that one of the reasons that assaults against

\footnotetext{
${ }^{56}$ PRO CO172/47: Civil and Judicial Establishments for 1827, Department of Roads and Bridges Blue Book 1825-7.

${ }^{57}$ IOL P/136/31: Phillips' Minute, 15 Apr. 1824.

${ }^{58}$ See for example: IOL P/140/73: E.A. Blundell, Commissioner Tenasserim Provinces, to R.D. Mangles, Secretary to Government Bengal, 4 Dec. 1835; IOL P/142/62: Inquiry into an outbreak of convicts on the Nyoung Ben Zeik Road (Tenasserim Provinces), 28 Dec. 1846.

${ }^{59}$ MA JA52: Verdict of the Court of Assizes, 1 Apr. 1834.

${ }^{60}$ IOL P/142/17: G.D. Coleman, Overseer of Convicts Singapore, to Butterworth, 26 Nov. 1843.
} 
convict overseers were relatively unusual is that the authorities appointed convicts who the others were afraid of. ${ }^{61}$ Was Ghunna's failure to pay what he owed to Rughobursing the motive behind his - and earlier Malagee Naragee's - attack, as Rughobursing claimed during his trial? That convicts in Mauritius were heavily involved in theft, trafficking, trading and capital accumulation is beyond dispute. ${ }^{62}$

Rughobursing also accused his European overseers of extortion, stating that they had told him that they would make him a commander on payment of a bribe. He had handed over the cash, but they had not done so. This allegation remains unsubstantiated, but other evidence does give it some credence. By all accounts, the overseers in Mauritius were a disorderly bunch, frequently absent from their work and fond of liquor. In 1820 , the Head of Convicts Francis Rossi wrote that he only had confidence in four of them 'the others being generally careless, inattentive, disobedient to orders and many of them given to drunkenness'. ${ }^{63}$ In 1830, an overseer on the Pamplemousses Road was taken off duty after he was caught selling moonshine liquor, distilled with the help of his convict working party. ${ }^{64}$ In Mauritius, a few convicts set themselves up as moneylenders; incredibly their clients included their overseers. In 1833, Overseer Thatcher claimed that the Chief Overseer himself, William Clover, owed one convict eighty shillings, another one hundred rupees and 'a very considerable amount' to several more. ${ }^{65}$ What provoked Rughobursing to attack Overseer Cormack some years before his arrest is a matter of

\footnotetext{
${ }^{61}$ As argued by Peter Zinoman for colonial Vietnam: The Colonial Bastille: A History of Imprisonment in Vietnam, 1862-1940, Berkeley, 2001, p. 112.

${ }^{62}$ Anderson, Convicts in the Indian Ocean, ch. 5.

${ }^{63}$ MA RA137: Rossi to Barry, 14 June 1820.

${ }^{64}$ MA Z2A59: Finniss to G.F. Dick, Secretary to Government Mauritius, 5 Feb. 1830.

${ }^{65}$ MA JB270: Overseer S. Thatcher to J.A. Lloyd, Surveyor General, 13 Sept. 1833.
} 
speculation. However, his claim that his Savanne overseers had extorted money from him was not entirely fanciful.

Overseer Simon Goss made a third claim about the motive for Rughobursing's assaults. He wrote that the attacks had a quite different motive: they were carefully calculated attempts to get off road gang labour. Goss wrote that convicts generally believed that they would better off in jail than on public works. After he had attacked Ghunna, Malagee Naragee had been sentenced to a year in prison. The other convicts regarded this as a holiday. He was convinced that Rughobursing had committed the assaults with this in mind. ${ }^{66}$ It is difficult to say whether Goss was attempting to shield his fellow overseers from disciplinary action, or whether these were genuine sentiments. His opinion was taken seriously at the time, however, for shortly afterwards, a Government Ordinance was passed, tightening up the regulations for the punishment of convicts convicted of certain secondary offences. ${ }^{67}$

Central to the secondary punishments dished out to convicts was their public display. With the exception of execution, the most dramatic of all punishments in this respect was flogging. Until 1852, convicts could be beaten with a rattan cane; both the flogging itself and the infections it often caused were severe. ${ }^{68}$ Occasionally, convicts died from its effects. In 1852, for instance, Mukkum Singh died after receiving twentyfive stripes in Arakan. The flesh on his back was said to resemble a 'half putrefied

\footnotetext{
${ }^{66}$ MA JB266: Overseer S. Goss to Lloyd, 13 July 1834.

${ }^{67}$ PRO CO169/2: Ordinance for the purpose of regulating the internal order and discipline of the prisons, 24 Feb. 1835 (Article 52).

${ }^{68}$ IOL P/144/20: Minute by the Governor of Bengal, 31 Mar. 1852.
} 
liver. ${ }^{69}$ Kalloo, a Bengali convict there, similarly succumbed to tetanus in $1854 .{ }^{70}$ Only fragmentary records survive, so it is impossible to measure the frequency of flogging, even if the records accurately enumerated the practice. Yet it is clear that it was not used very often. One record notes that just fourteen out of the 1319 convicts living in Singapore in 1845 were flogged. ${ }^{71}$ No matter how many convicts were actually flogged, however, all convicts worked under the threat of the cane and would have been aware of its power. Floggings were administered in full view of convict working parties, usually on muster day when all were present. As Coleman wrote in 1844, this ensured floggings had 'the greatest degree of publicity. ${ }^{72}$ In Mauritius, they took place either at the Grand River headquarters or a punished convict's working party in his district. ${ }^{73}$

Public executions were even more dramatic. In 1805, Connye Tackoor was sentenced to hang in Bencoolen. He was taken to the place of execution in front of all the remaining convicts, and only then told that his sentence had been commuted. ${ }^{74}$ The purpose of this was to show the convict body that the authorities had the power to enforce the sentence if they so desired. The Resident of Bencoolen, T. Parr, wrote two years later

\footnotetext{
${ }^{69}$ IOL P/144/20: Report of A.P. Phayre, Commissioner of Arakan, 18 Feb. 1852; History of the case of a prison named Mohcum Sing who died from the effects of flogging, J Kearney, Sub-Assistant Surgeon, 28 Jan. 1852.

${ }^{70}$ IOL P/144/54: Hopkinson to Pratt, 20 Jan. 1854.

${ }^{71}$ IOL P/142/37: Present System of Management and Discipline of Convicts at Singapore, Superintendent D.A. Stevenson, 9 Jan. 1845.

${ }^{72}$ IOL P/142/17: Coleman to Butterworth, 26 Nov. 1844. J.F.A. McNair, Comptroller of Indian Convicts Strait Settlements, 1857-1877, describes the scene in Prisoners Their Own Warders: A Record of the Convict Prison at Singapore in the Straits Settlements established 1825, Discontinued 1873, together with a Cursory History of the Convict Establishments at Bencoolen, Penang and Malacca from the Year 1797, Westminster, 1899, p. 88.

${ }^{73}$ PRO CO415/15: Memorial of Farquhar, 28 Oct. 1817.

${ }^{74}$ IOL P/129/22: Parr to Udny, 20 Nov. 1805.
} 
that the commutation of Tackoor's sentence had led to an increase in convict crime, and ordered the execution of three convicts - Beggah, Azeem Deenoo Neetoo and Berkutoolah - for offences against property. ${ }^{75}$ He later noted the effects of the hanging: 'the submissive and peaceable behaviour of the convicts has exhibited a remarkable contrast to the contumacious and refractory spirit which they manifested previously to that event. ${ }^{76}$ He repeated this sentiment after thirty men made their escape in 1809 , requesting permission to execute all recaptured convicts as a lesson to the remainder. ${ }^{77}$

The threat or actuality of the beating of a convict on the flogging triangle, or his last drop on the scaffold, were theatrical performances where power relations were consolidated. ${ }^{78}$ Moreover, convicts themselves were absorbed into this ritual of punishment and, on occasion, resistance. When Mukkum Singh was flogged, three of his fellow convicts were made to hold the triangle's stabilising ropes. ${ }^{79}$ When another convict was taken to be flogged in the Tenasserim Provinces, he resisted being put in the stocks, and four other convicts attempted to rescue him from the triangle. ${ }^{80}$ These scenes, of some holding up a fellow convict for punishment, whilst others attempted to prevent it, are neat metaphors for the way in which convicts were both implicated in and resisted punishment.

\footnotetext{
${ }^{75}$ IOL P/129/32: Parr to Udny, 15 Aug. 1806.

${ }^{76}$ IOL P/129/42: Parr to G. Dowdeswell, Secretary to Government Bengal, 7 Nov. 1807.

${ }^{77}$ IOL P/132/2: Parr to Dowdeswell, 4 Feb. 1809.

${ }^{78}$ Raymond Evans and Bill Thorpe, 'Commanding Men: Masculinities and the Convict System', Journal of Australian Studies, 56 (1998), pp. 22-4.

${ }^{79}$ IOL P/144/20: Interview of W. Columbs, Jailor Kyaukpyu, 5 Feb. 1852.

${ }^{80}$ IOL P/142/29: J. Moore, Assistant to the Commissioner Mergui, to H.M. Durand, Commissioner Tenasserim Provinces, 7 Jan. 1845.
} 
The truth or otherwise of the multiple narratives of Rughobursing's experiences of transportation are less important than what can be extrapolated from them about the operation of the convict system. Despite the discourse of penal labour, the system held out limited freedoms to convicts. Penal settlements were porous institutions. Convicts had some freedom of movement, and engaged in entrepreneurial activities. Hierarchies of punishment were also blurred. The socio-economic relationships between Indian convicts and their European overseers were complex, and convicts too were integrated into the penal hierarchy. To some extent, then, convicts determined elements of their experience of colonial punishment, as Rughobursing's claims about what precipitated the assaults show. If Overseer Goss was correct in his assertions about the motive for Rughobursing's attack on commander Ghunna, however, his attempt to manipulate the boundaries of his punishment was a fatal mistake, for ultimately the colonial authorities determined those. Rughobursing overstepped the mark, and instead of enjoying a break from road labour in jail, met his fate on the guillotine. As convict Connye Takoor, petitioning for the commutation of his recently passed capital sentence in Bencoolen, wrote in 1805: 'I am the Company's slave, whether I have, or have not stolen the Company[']s goods is now out of the question, I have been convicted ... I am a poor Brahmin, you are Ruler. ${ }^{81}$

${ }^{81}$ IOL P/129/22: Petition of Connye Takoor, 27 Oct. 1805. 